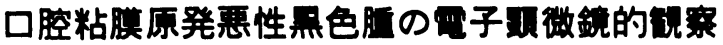

\author{
平野吉雄・大濑周作・的橋婜 \\ 古田正产・川合一・村田㨫少

\section{Electron microscopic studies of primary malignant melanoma of oral mucosa}

\author{
Yoshio Hirano - Syusaku Ose - Masaru Takahashi \\ Masahiko Furuta - Hajime KawaI - Mutsuo Murata
}

\section{耤}

\section{함}

melanin 産生湅胞である melanocyte の增殖により生 じ德性盾要としての悪性黒色盾は，皮后に好発するが まれに粘䐜，眼球，神経系その他にる原発する。本邦に おいて口腔粘膜に原発した悪性黒色腯の光学暊徽鏡的検 索はこれまで数多く報告されているい゙）しかし奄子顕 酸鏡的誢察は少ないのー8)，今回われわれは口腔粘膜に原

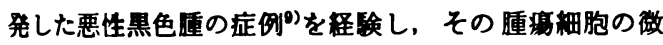
細棬造を奄子影钽鏡的に検索したので報告する。

\section{材料および方法}

59歳男子, 色素沈着を有する $1 \underline{1 \sim 3}$ の重瘤を主訴とし て来科，绎過および肉眼的所見より，悪性黒色庫の診断 のもとに治療方針決定後，電影的锶察のため，循瘤部よ り組黄を採取し，直ちに2.5\%クルタールフルデヒド溶 液で 2 時間固定, $5.4 \%$ クルコース加镂酸稂街液で 24時 間洗浄，次いで $1.0 \%$ オスミウム酸溶液で 1 時間半固定 後，上昇アルコールおよびアセトンで脱水した，その後 通法に従いエポン 812 で包埋し，超薄切片作製後，酢酸 ウラニールとクェン酸鉛で 2 重染色を施し，龟子影微鏡 で铸察した。

\section{結果}

基底沺胞首を構成する細胞において，軽度の病変が られる部位の細胞では，核は比较的凹凸が少なく，円形 または棈円形を示するのが多く，クロマチン顆粒はおお

三大学医学部口貯外科学教室（主任：村田睦男教 投)

Department of Oral Surgery, School of Medicine, Mie University (Chief: Prof. Mutsuo Murata)

受付日：昭和56年 3 月 25 日
むね均筫に分布していた，核小体は核筫より電子密度が 高く、顆粒があたかも円形に擬集したよらな像を呈して いた。核質内には spherical body 棣の核内小体が琶め

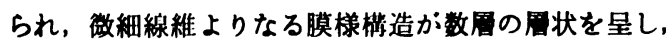
中心部に melanin 色秦と思われる電子密度の高い顆粒

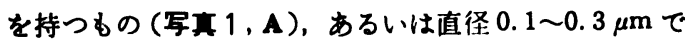
電子密度の異なる種々の顆粒が集合し，その周囲を徽細 線䊒よりなる膜粎構造がりかこんでいるるの（写真 1，B）などがあり，これらはいずれる周囲核質とは Haloで分離されていた，病変が進むに従い melanin 色 素様顆粒が明瞭に認められるよらになった，核膜の凹凸 は顥著ではないか，核質中にはかなりの空胞が出現して いる. さらに進行すると，細胞質内には長径約 $0.7 \mu \mathrm{m}$ の多量の melanosome が出現し，核膜の凹凸は著しくな り核内の大部分は種々の大きさの空胞および melanosome で占められた。 また核内に多数のミェリン様構造 を持つるのも認められた（写真 2).

中間層の 棘細胞層においては, 初期には desmosome はよく保存されており，それに続く tonofilament る明 瞭に存在していた。しかし acantholysis を起こしている 細胞では desmosome は消失し，それに繶く tonofilament る認められなかった。 また束状になった tonofilamentに 横紋か出現し，あたかる骨格筋の Z-band のよらな構造 を認めるが，横紋の幅や間隔は一様でなく退行性変化で はないかと考えられた（写草了，4）.

上皮下層を形成する細胞においては、ゴルジー装置が 非常によく発達し、ゴルジーラメレの一端が桩大し, 膜 の肥厚と電子密度の增加があり, 遊離して coated vesicle に移行し，この coated vesicle の内部の電子密度が次第 に增加して premelanosome になると思われる所見が認 められた。 このことはコルジー装置での melanin 形成 過程をらかがわせた（写真 5). しかし粗面小胞体や free ribosome は比較的少なく，分泌細胞にみられるよらな 発達した粗面小胞体とゴルジー装置との密接な関係を示 す所見は少なく，むしろミトコンドリアが多数認められ 
た。また細胞によっては細胞筫内に紐状を!是する構造物 がみられ，その周四にも premelanosome お。び melanosome が多数みらけられた（军木6). しかしこの紐状 橵造物の起源は明らかでない. premelanosome が綐断

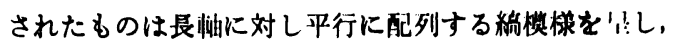

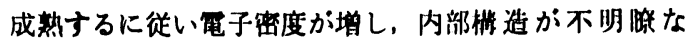
melanosome へと移行した（字南 7)。このらち顆料の 集合したものは腯細胞といらよりはむしろ、マフロフ フージに貝食されたすのと思われ，その中に premelanosome から melanosome に至る数十から数百の顆䊀か; 認められた（写真 8 ）。 また $2.7 \times 1.7 \mu \mathrm{m}$ の大きさの

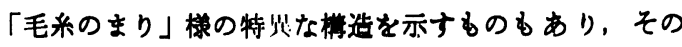
内部には premelanosome に特有な縞棪様がらられ，な んらかの理由で premelanosome が洖集したのではない

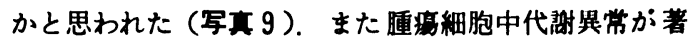
しくなったと思われる細胞においてはミトコンドリフか 增加し，その形態も带状に極端に細長くなり，クリステ の方向も一様でなかった（写直10）.

\section{考察}

一般に口腔粘膜原発の悪性黒色腫は比較的まれな重暍 とされており ${ }^{10)}$ ，悪性庫瘍の特徵としては，細胞および 核の不整化，核および核小体の增大，クロマチン量の增 加, 細胞内小器官の発達があげられる11) 本症例におい ても核が非常に大きく，深い切れ込みを有する分葉状を 呈するすのが多く，クロマチンに富み，大きな核小体と 複雑な核内小体の形成がみられ,これらの所見は上記電 顕レベルでの悪性腫易の一般的特徵に一致していた。同 時に悪性黒色腫に特徵的な形態である premelanosome および melanosome が多量に細胞内に分布していた。こ の melanosome および premelanosome なる言葉は1965 年の国際色素学会にて緒一語として定められた。 それに よると melanosome とは melanin 合成が完了し，チロ ジナーセ活性がなく，電子密度の均一なるのとされ，一 方 premelanosome とはチロジナーぜ活性があり, melanin 成熟過程における電子密度の種々段階のものと定 義されている12)

悪性黒色腫における melanin 形成の場については, (1)ミトコンドリア説 ${ }^{13)},(2)$ 核説 ${ }^{14)},(3)$ ゴルジー装 置説 ${ }^{15 \sim 17)},(4)$ 粗面小胞体説 ${ }^{18 \sim 20)}$ など種々みられるが, 現在ではゴルジー装置が melanin 形成の場であり，そ れに粗面小胞体が関与しているのではないかといわれて いる. すなわち Seiji ら ${ }^{21 \sim 23)}$ は, 分画遠心分離法および ラジオフイントーブを用いた実験から， ribosome でチ ロジナーゼが合成され，小胞体をへてゴルジー装直に運 ばれ，そこで選択的に小空胞に集められ，次いで空胞内 で一定の配列をとり蓄積され，できあがった premelanosome および melanosome 上で melanin 形成が始ま
り、形成された melanin が premelanosome およひ melanosome の腆トに沈着すると述ぺている，われかれ

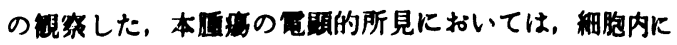
Sciji ら 21 28)の指据しているよらな粗面小胞体の咟著な

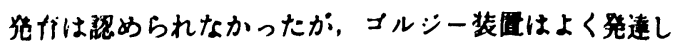
ており，その周辺には积々の大きさの消面小胞体が存在 し, 间時に free ribosome, premelanosome, melanosome,

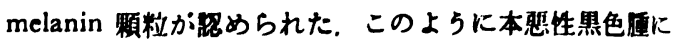
おいても，melanin 形成の场はコルジー装圈であろらと 思われた。一方值々の段倩の premelanosomeおよひ melanosome が密集し，集塊状を呈している所見は，正

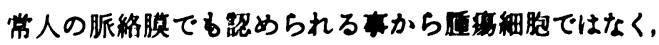
マクロファーシに食食されている所見ではないかと思わ れた。

melanocyte の起源については，一般的には胎生期の neural crest と考えられ，これか，外还藮由来のため，同 侎に外胚菜由来の schwann 細胞と melanocyte との関 係が考えられている. しかし現在では Bierring らクおよ

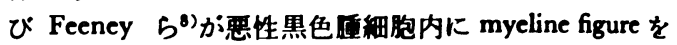
認めたことから schwann 細胞説が有力視されている.

\section{結}

\section{郭}

59藏男子の $\mid \underline{1 \sim 3}$ 部口腔粘獏に原発した悪性黒色稙の 生検材料を電影的に钼察し以下の知見を得た。

1）腫場細胞は紡鍾形または棈円形を呈し，その核は おおむね大型で不整形を呈するるのが多かった。核小体

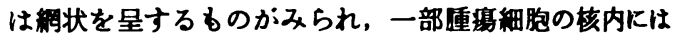
ミェリン様構造を呈するるのがあった。 また核小体の周 囲には spherical body様でかなり褯䊒な檴造物を含む 核内小体がみられた。

2) 腫場細胞の細胞質内には，上く発達したコルジー 装置, 細長い:トコンドリフ, free ribosome がみられ, そのよく発達したゴルジー装置を中心として，滑面小胞 体, 龟子密度の高い空胞, および種々段階の premelanosome, melanosome が覞察され melanin 形成の場㤝 ゴルジー装眉ではないかと考える.

3 ) premelanosome, melanosome および melanin 顆 粒をきわめて多数包含する細胞は melanocyte ではなく これらを領食したマクロファージと思われる。

本論女の要旨の一部は，1978年 5 月18日第32回日本口 腔科学会総会において発表した。

\section{引用 文 嗝}

1）今井忠治，他：口腔内に原発した悪性黒色盾の 2 例。口科誌 18: 2361969.

2）渡匄義男, 他：上額部悪性黒色尰の 2 症例につ 
いて。口科誌 16: 1681967.

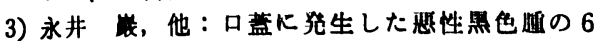
例飞ついて。阪大学 12: 2931967.

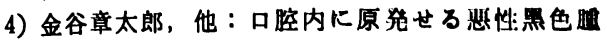
の 4 例，京大口科粑要 7:65 1967.

5) 浜田健一。他：口蓝の malignant melanoma の 1 例。 日外誌 23: 1291977.

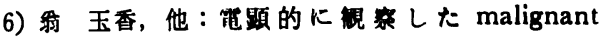
melanoma $の 1$ 例。口科誌 21: 181972.

7) Bierring, F.,et al.: Electron microscopy of malignant melanoma of the choroid. Acta Ophthal 41: 2241963.

8) Feeney, L., et al.: Electron microscopy of the human choroid. Amer J Ophthal 51: 10571961.

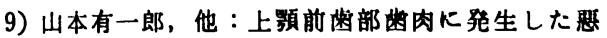
性黒色畽の 1 例。日口外誌 27：619 1981 .

10)高木央, 他：日本人における口腔粘膜原発の 要性黒色腫。口病誌 38: 3911971.

11）太田邦夫：東 昇䋍: 医学生物学用電子頙碳鏡 学. 第 3 版, 文光堂, 東京, 1961，409頁.

12) Fitzpatrick, T.B., et al.: The evolution of concepts of melanin biology. Arch Derm 96: 3051967.

13) Woods, M., et al.: The ontogenic status of melanin granules. Ann N Y Acad Sci 100: 5341963.

14) Françis, J., et al.: Electron-microscopic data on pigment formation in melanoblastoma. Arch Ophthal 64: 3771960.
15) Birbeck, M.S.(.: Electron microscopy of melanocytc. Ann N Y Acad Sci 100: 5401963.

16) Wellings, S.R., et al.: Electron microscopic studies on subcellular origin and ultrastructure of melanin granules in mammalian melanomas. Ann N Y Acad Sci 100: 5481963.

17) Wellings, S.R., et al.: Role of golgi apparatus in the formation of melanin granules in human malignant melanoma. J Ultrastruct Res 3: 1471959.

18) Zelikson, A.S., et al.: Melanogenesis: An autoradiographic study at the ultrastructural level. J Invest Derm 43: 3271964.

19) Zelikson, A.S.: The fine structure of the human melanotic and amelanotic malignant melanoma. J Invest Derm 39: 6051962.

20) Moyer, F.H.: Genetic effects on melanosome fine structure and ontogeny in normal and malignant cells. Ann N Y Acad Sci 100: 584 1963.

21) Seiji, M., et al.: Inter cellular localization of tyrosinase and site of melanin formation in melanocyte. J Invest Derm 45: 3051965.

22）消寺 近，他：恐性黒色近の分子生物学. 取新 医学 23: 5551968.

23) Seiji, M., et al.: A distinctive subcellular particle of mammalian melanocytes and the site of melanogenesis. J Invest Derm 36: 243 1961. 


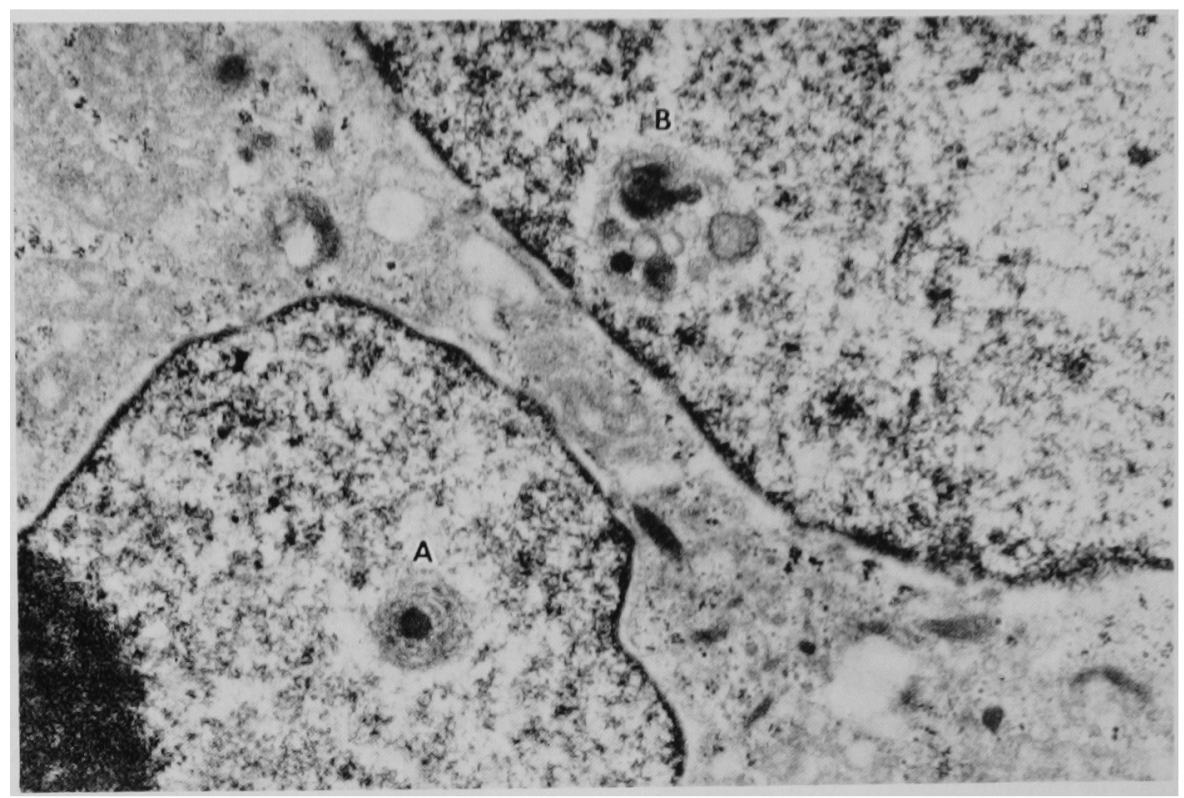

写真 1 情内にみられた核内小体，基底細胞層 $(\times 24,000)$

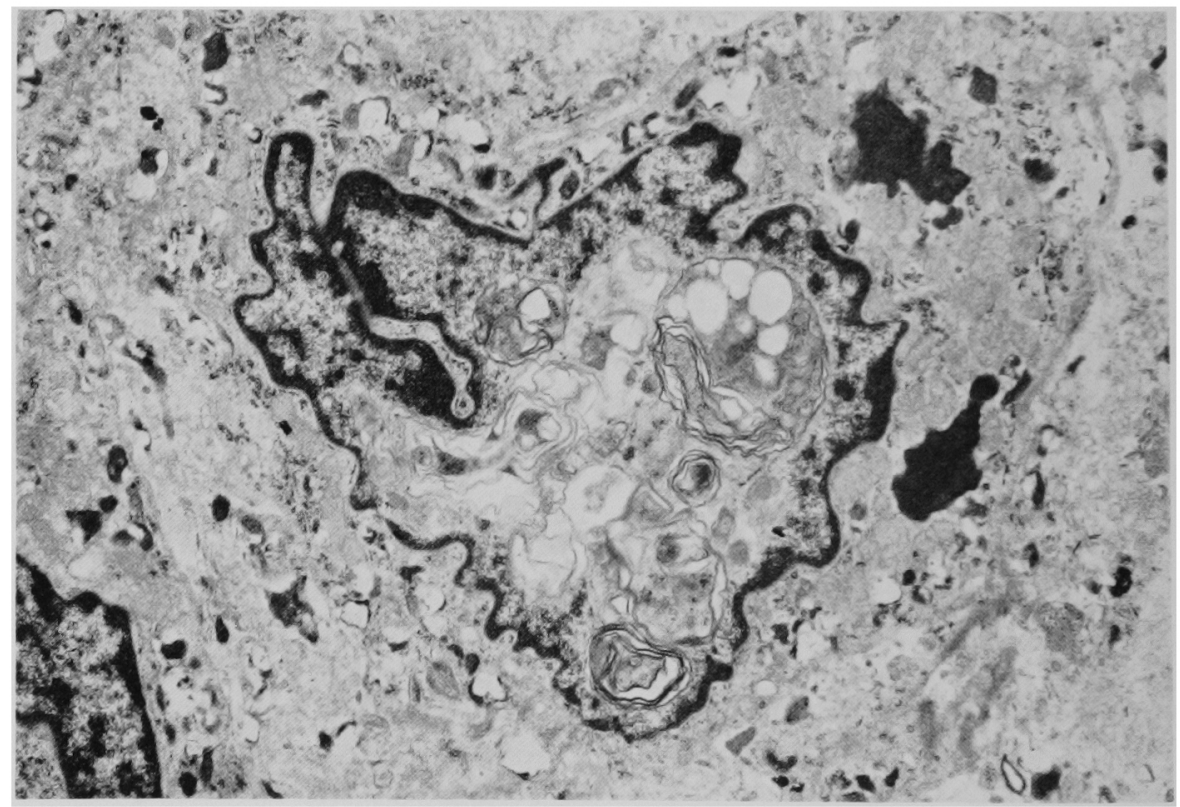

写真 2 核内にみられた空胞とミュリン様構造, 基底勫胞層 $(\times 25,000)$ 


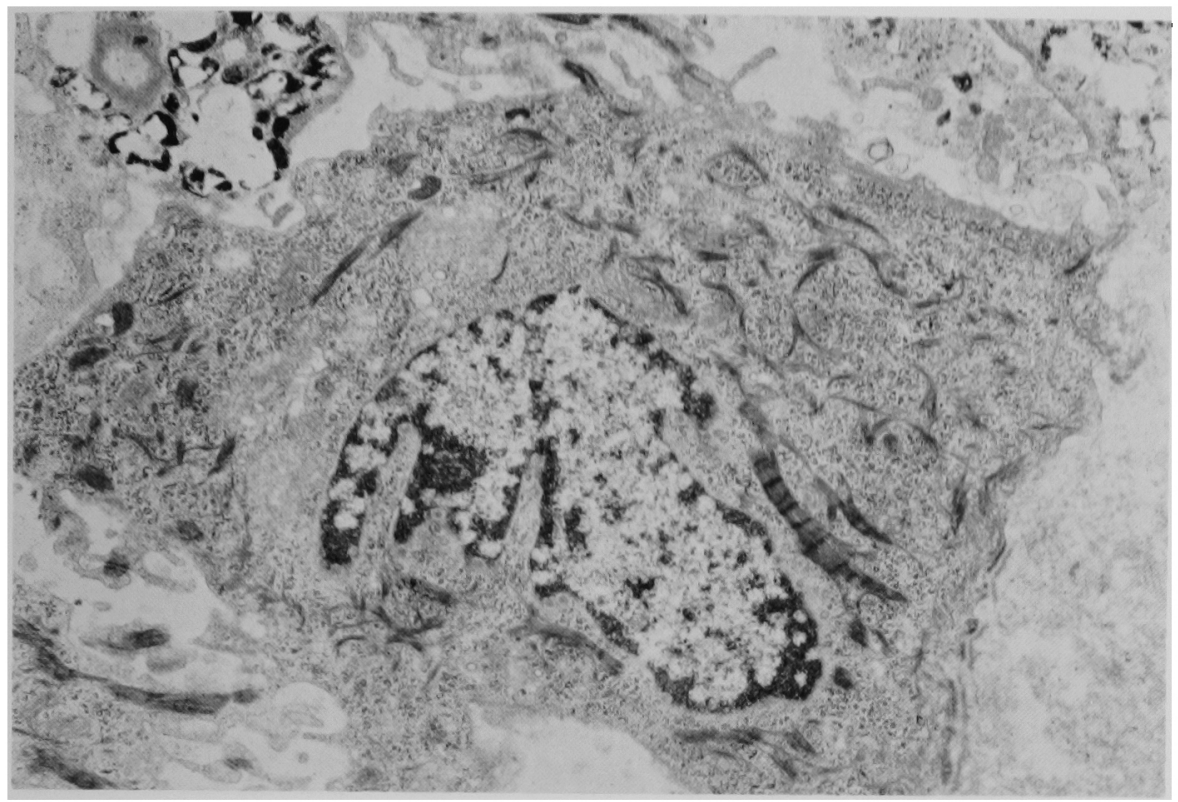

写真 3 梱胞算内に多量にみられた tonofilament, 中間闭 $(\times 14,000)$

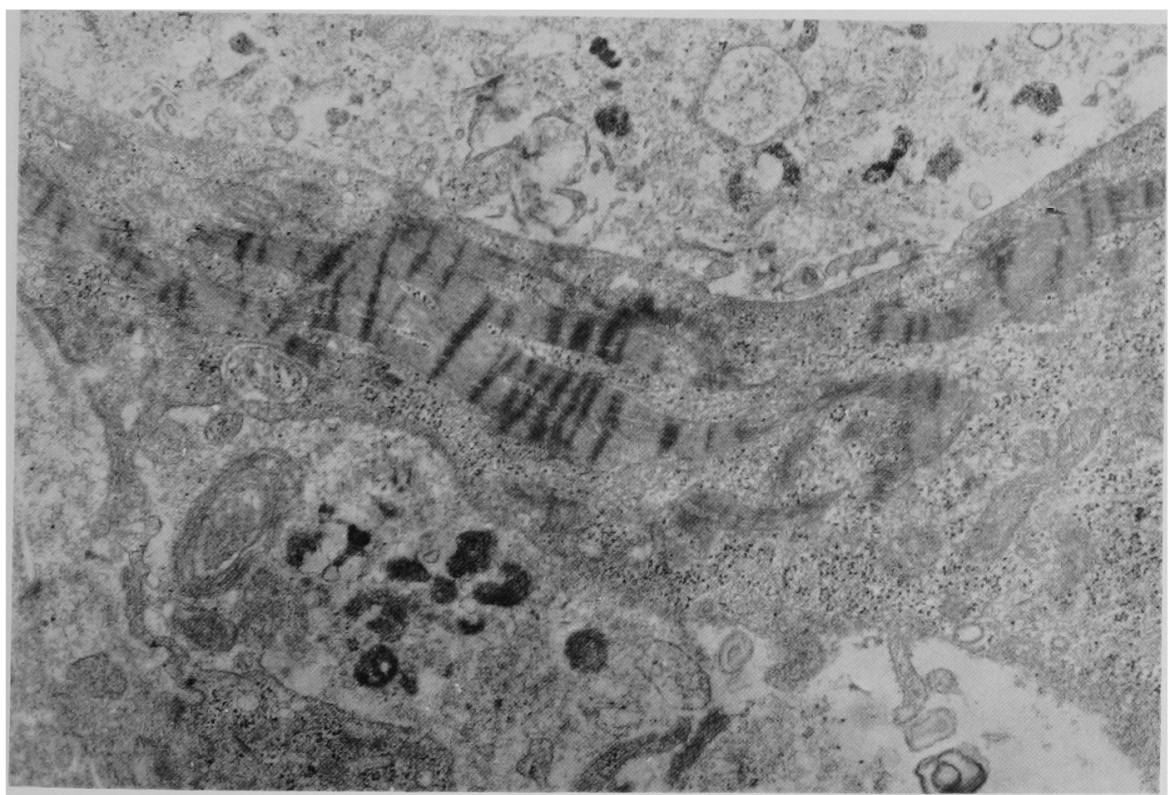

写真 4 骨格筋の Z-band 様構造を呈する束状 tonofilament, 中問層 $(\times 23,000)$ 


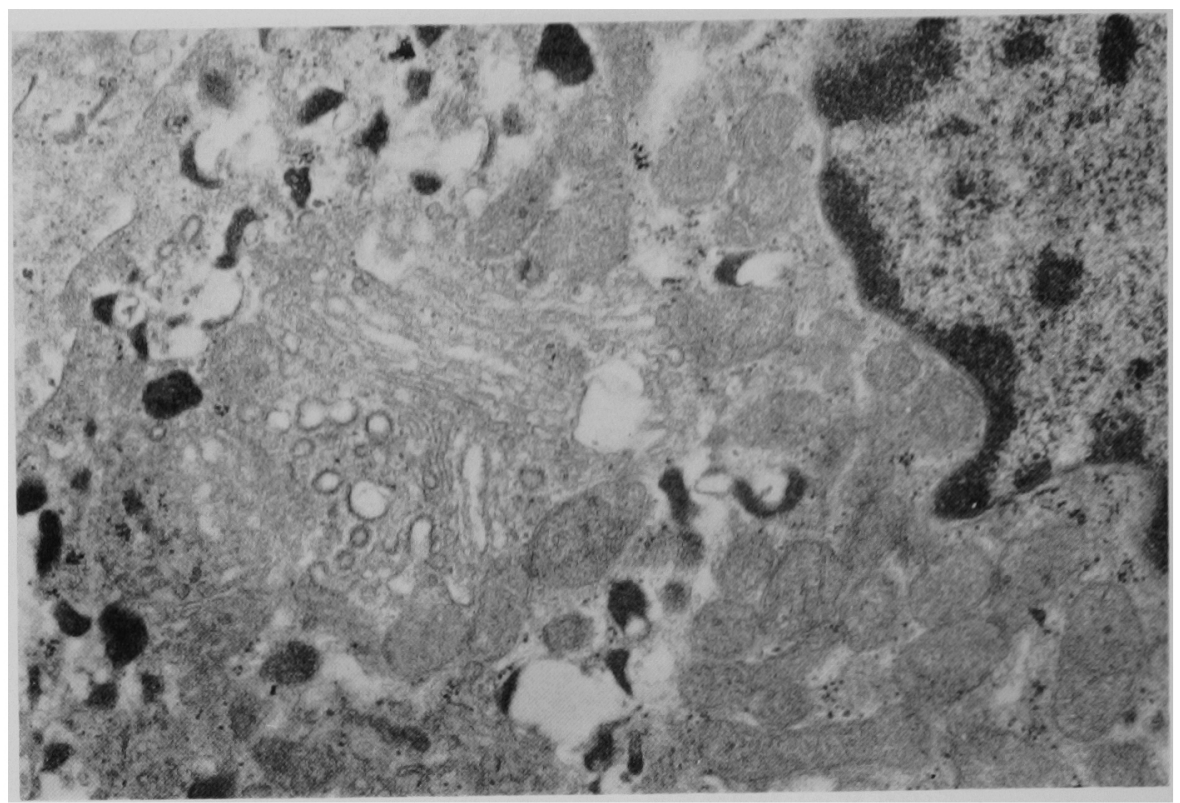

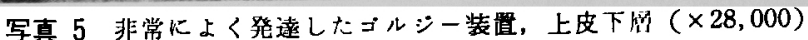

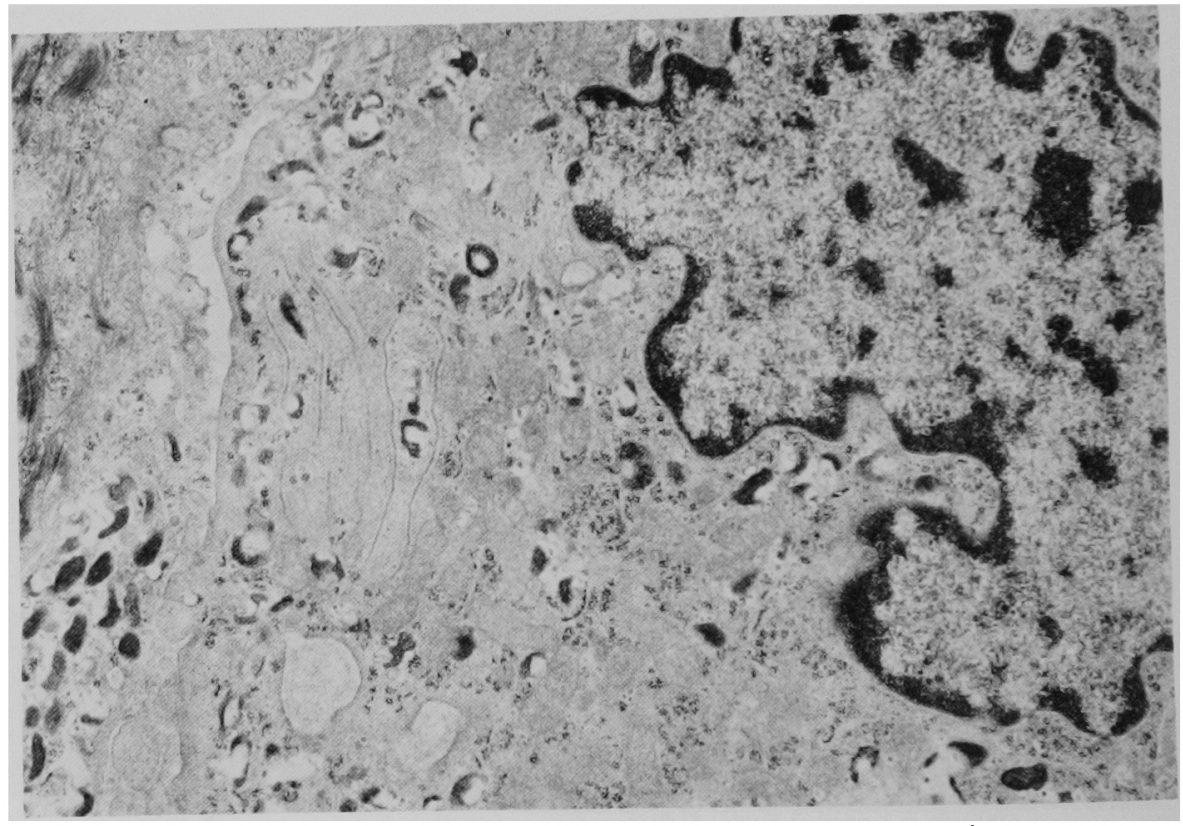

写真 6 稩胞質内にみられた紐状構造物，上皮下層 $(\times 15,000)$ 


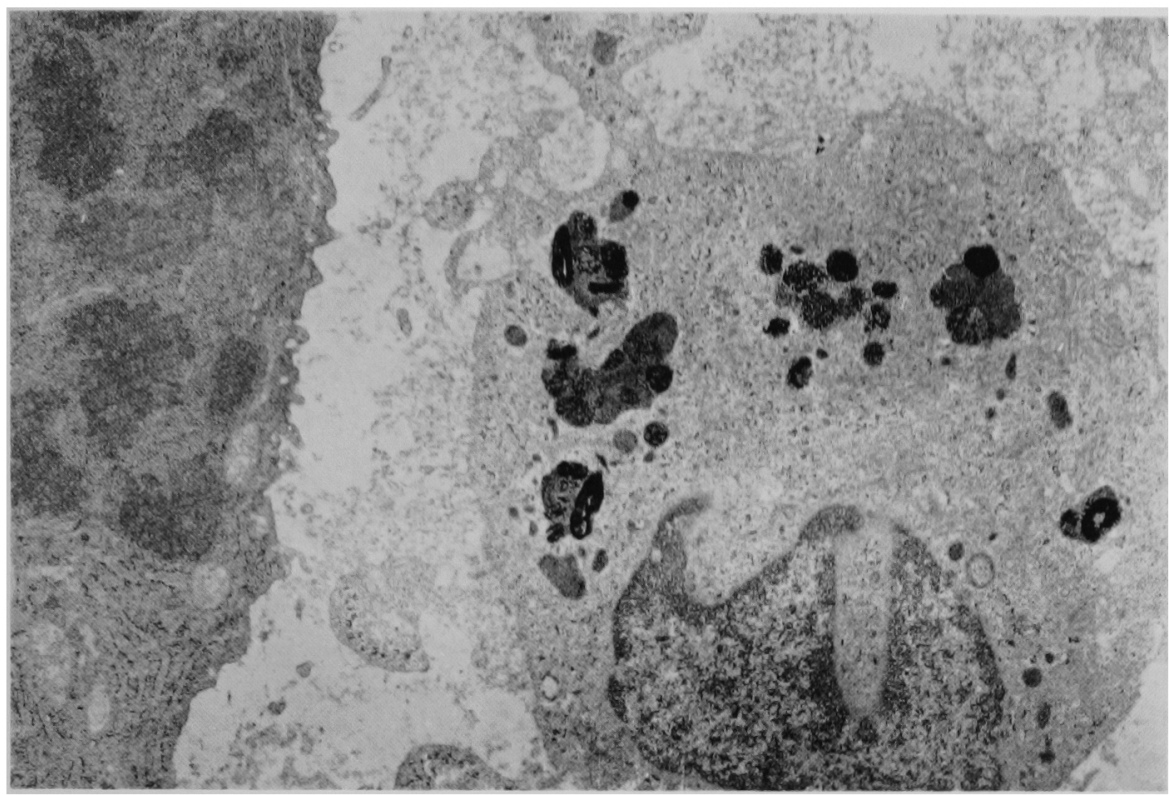

写高 7 細胞嘪内にみられた premelanosome および melanosome $(\times 10,000)$

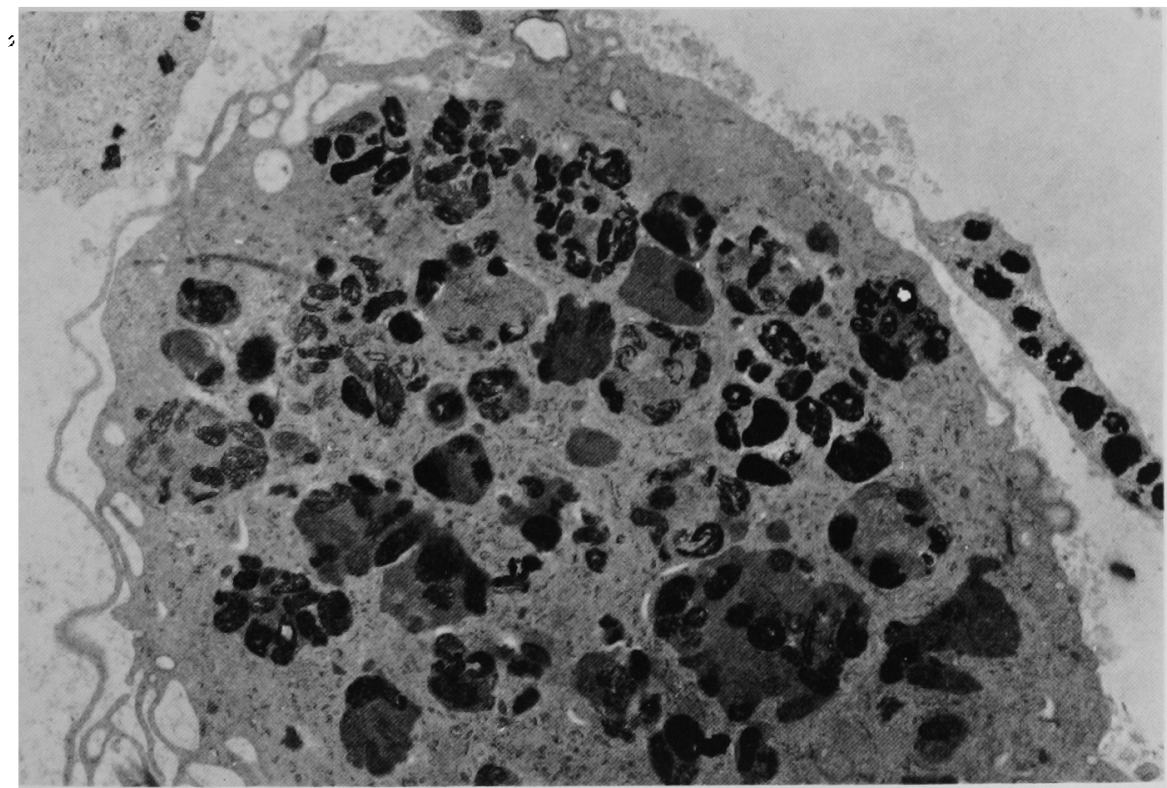

军真 8 マクロファージ奝食された premelanosome 扰よび melanosome ( $\times 10,000)$ 


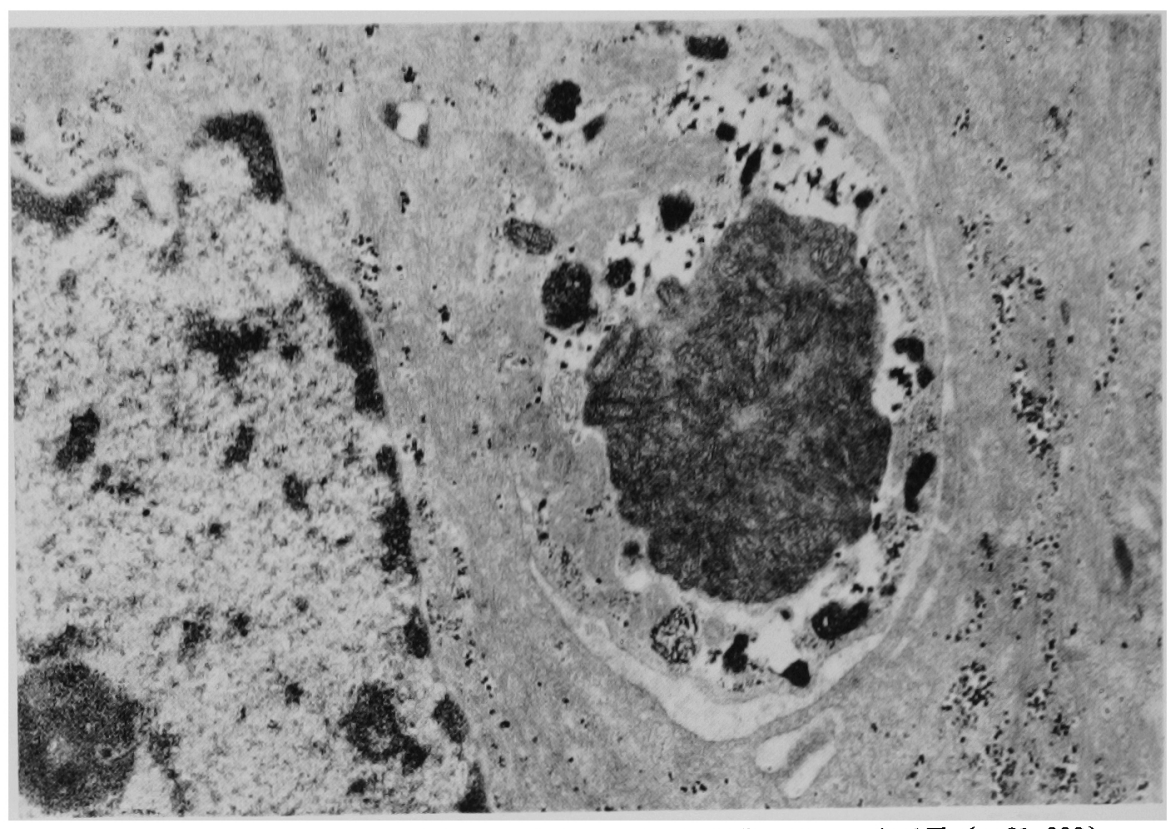

写真 9 premelanosome が凝集した「毛手のまり」状構造物，上皮下層 $(\times 21,000)$

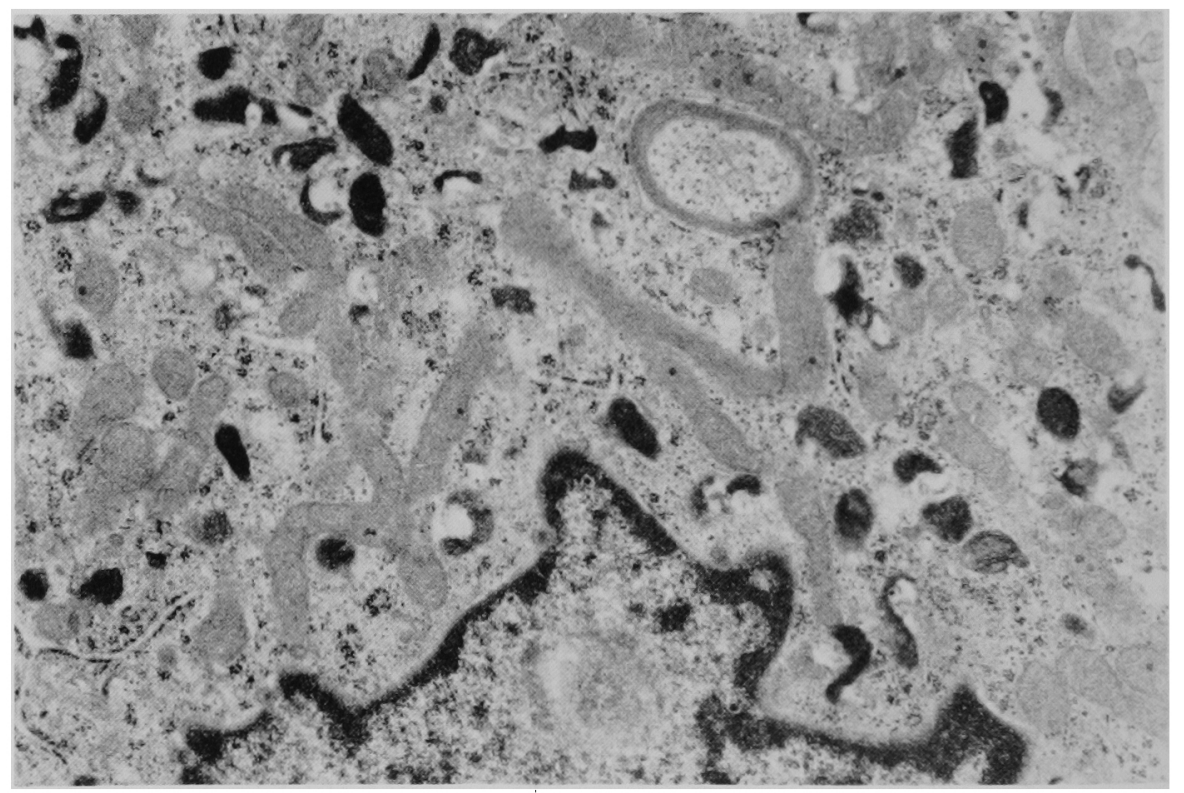

写真 10 細胞質内にみられた細長い带状ミトコンドリア，上皮下層 $(\times 20,000)$ 